\title{
Combined metabolome and proteome analysis of the mantle tissue from Pacific oyster Crassostrea gigas exposed to elevated $p \mathrm{CO}_{2}$
}

\author{
Lei Wei ${ }^{\mathrm{a}, \mathrm{d}}$, Qing Wang ${ }^{\mathrm{a}}$, Xuanxuan Ning ${ }^{\mathrm{b}}$, Changkao Mu ${ }^{\mathrm{c}}$, Chunlin Wang ${ }^{\mathrm{c}}$, Ruiwen Cao ${ }^{\mathrm{a}, \mathrm{d}}$, Huifeng Wu ${ }^{\mathrm{a}, *}$, \\ Ming Cong ${ }^{\mathrm{a}}$, Fei $\mathrm{Li}^{\mathrm{a}}$, Chenglong Ji ${ }^{\mathrm{a}}$, Jianmin Zhao ${ }^{\mathrm{a}, * *}$

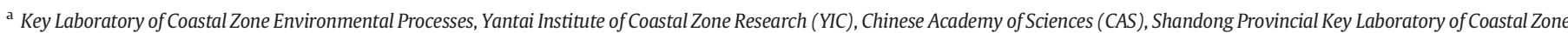 \\ Environmental Processes, YICCAS, Yantai 264003, PR China \\ b Yantai Oceanic Environmental Monitoring Central Station of SOA, Yantai 264006, PR China

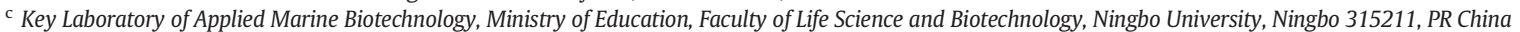 \\ ${ }^{\mathrm{d}}$ University of Chinese Academy of Sciences, Beijing 100049, PR China
}

\section{A R T I C L E I N F O}

Article history:

Received 9 September 2014

Received in revised form 10 December 2014

Accepted 12 December 2014

Available online 20 December 2014

\section{Keywords:}

Ocean acidification

Proteomics

Metabolomics

Crassostrea gigas

\begin{abstract}
A B S T R A C T
Ocean acidification $(\mathrm{OA})$ has been found to affect an array of normal physiological processes in mollusks, especially posing a significant threat to the fabrication process of mollusk shell. In the current study, the impact of exposure to elevated $\mathrm{pCO}_{2}$ condition was investigated in mantle tissue of Crassostrea gigas by an integrated metabolomic and proteomic approach. Analysis of metabolome and proteome revealed that elevated $p \mathrm{CO}_{2}$ could affect energy metabolism in oyster $C$. gigas, marked by differentially altered ATP, succinate, MDH, PEPCK and ALDH levels. Moreover, the up-regulated calponin-2, tropomyosins and myosin light chains indicated that elevated $p \mathrm{CO}_{2}$ probably caused disturbances in cytoskeleton structure in mantle tissue of oyster $C$. gigas. This work demonstrated that a combination of proteomics and metabolomics could provide important insights into the effects of $\mathrm{OA}$ at molecular levels.
\end{abstract}

(C) 2014 Elsevier Inc. All rights reserved.

\section{Introduction}

Since the inception of the Industrial Revolution, the concentration of atmospheric carbon dioxide $\left(\mathrm{CO}_{2}\right)$ has increased from 280 to ca. $400 \mathrm{ppm}$ due to human activities. The oceans absorbed about $30-50 \%$ of global $\mathrm{CO}_{2}$ emitted from all anthropogenic sources (Feely et al., 2004; Sabine et al., 2004), causing a progressive increase in ocean inorganic carbon concentrations and resulting in a decrease in $\mathrm{pH}$ and carbonate ion concentration, a phenomenon known as ocean acidification (OA). As a consequence, average sea-surface $\mathrm{pH}$ has lowered by 0.1 units since the start of the Industrial Revolution, and is expected to reduce by $0.3-0.4$ units in 2100 and up to 0.7 units by the year 2300 (Caldeira and Wickett, 2003; Intergovernmental Panel on Climate Change (IPCC), 2007). OA has been reported to affect ocean biota, but the severity varies greatly depending on the organisms considered. Accumulating evidences revealed that the alteration of seawater $\mathrm{pH}$ had negative effects on the survival, calcification, growth and development of sea creatures (Hönisch et al., 2012), especially marine calcifiers such as mollusks, corals and echinoderms (Doney et al., 2009; Jury et al., 2010).

As typical calcifying organisms, published studies reported that mollusks became more difficult to deposit their calcium carbonate

\footnotetext{
* Corresponding author. Tel.: +86535 2109190; fax: + 865352109000

** Corresponding author. Tel.: + 86535 2109170; fax: + 865352109000

E-mail addresses: hfwu@yic.ac.cn (H. Wu),jmzhao@yic.ac.cn (J. Zhao).
}

$\left(\mathrm{CaCO}_{3}\right)$ shells and suffered a range of negative impacts including reduced shell mass and strength under the exposure of acidified seawater (Welladsen et al., 2010; Gazeau et al., 2013). The mollusk shell secreted by the mantle epithelial cells was thought to play a vital role in protection from predators, parasites and unfavorable environmental conditions. Due to the vulnerability of shell deposition to predicted near-future levels of $\mathrm{OA}$, the mantle tissue has received much attention. For example, the expression of genes associated with energy metabolism and periostracum formation was increased in the mantle tissue of blue mussel Mytilus edulis under elevated $p \mathrm{CO}_{2}$ exposure (Hüning et al., 2013). Lannig et al. (2010) reported that alanine and ATP levels decreased significantly under elevated $p \mathrm{CO}_{2}$ exposure in mantle tissue of oyster $C$. gigas, indicating shifts in metabolic pathways following $\mathrm{OA}$-exposure. Furthermore, exposure to high $\mathrm{pCO}_{2}$ resulted in significant proteome shifts in the mantle tissue of eastern oyster Crassostrea virginica, especially proteins associated with the cytoskeleton and oxidative stress (Tomanek et al., 2011).

Pacific oyster $C$. gigas is the most widely cultivated and harvested shellfish in the world (Higuera-Ruiz and Elorza, 2009), and has been used as a model organism in marine environmental research. Previous studies have found that exposure of $C$. gigas to elevated $p \mathrm{CO}_{2}$ led to various abnormal phenomena such as fertilization failure, reduced shell deposition, disruption of shell ultrastructure and disturbances in energy metabolism (Beniash et al., 2010). For example, Parker et al. $(2009,2010)$ found that the fertilization and development of oysters 
Saccostrea glomerata and $C$. gigas were impaired under elevated $p \mathrm{CO}_{2}$ exposure. Notably, intraspecific variation of the responses to elevated $p \mathrm{CO}_{2}$ was observed between wild-type and a selectively bred Sydney rock oyster $S$. glomerata. The selectively bred population appeared more resistant than the wild-type at low pH (Parker et al., 2011, 2012). Recently, a comparative proteomic analysis revealed that expression of proteins related to calcification and cytoskeleton production in C. gigas appeared to be severally suppressed by OA stress (Dineshram et al., 2012). Due to the complex physiological responses of mollusks to OA stress, integrating multiple '-omic' analysis is essential to fill the gaps in our understanding the underlying mechanisms responsible for adaptation or acclimation (Evans et al., 2013; Tomanek, 2014). In this work, we applied metabolomics and proteomics to elucidate the effects and the molecular mechanisms in mantle tissue of Pacific oyster $C$. gigas under elevated $p \mathrm{CO}_{2}$ exposure.

\section{Materials and methods}

\subsection{Animal collection and exposure}

Juvenile oysters $C$. gigas (shell length: $2-4 \mathrm{~cm}, n=120$ ) were purchased from a local culture farm (Yantai, China), and acclimatized in normal aerated seawater (approx. $\mathrm{pH} 8.18, \mathrm{pCO}_{2} 428 \mathrm{ppm}$, temperature $18{ }^{\circ} \mathrm{C}$ and salinity 29\%o) for 2 weeks before commencement of the experiment.

The juvenile oysters were randomly divided into six assigned tanks. Two $\mathrm{pH}$ treatment levels ( $\mathrm{pH} 7.6$ and 8.2) were targeted with three replicate tanks per treatment level. These $\mathrm{pH}$ levels encompassed potential mean oceanic $\mathrm{pH}$ levels estimated for the current oceans and predicted for future oceans (to the year 2300). In the present study, the ambient seawater was used as control ( $\mathrm{pH}$ 8.18) bubbled with the atmospheric air. For elevated $\mathrm{pCO}_{2}$ treatment, the $\mathrm{pH}$ level was maintained by continuously bubbled with air- $\mathrm{CO}_{2}$ mixtures (approx. $2013 \mathrm{ppm} \mathrm{CO} \mathrm{CO}_{2}$ ). The $\mathrm{CO}_{2}$ concentration was adjusted through air and $\mathrm{CO}_{2}$ gas flow adjustment system (CE100-3, Wuhan Ruihua Instrument \& Equipment Co. Ltd, PR China). Appropriate levels of turbulence were achieved by utilizing air diffusers to deliver the air- $\mathrm{CO}_{2}$ gas mix into each experimental tank. Seawater was renewed every other day using pre-bubbled seawater which had been equilibrated previously. During the acclimation and experimental periods, the oysters were fed with a commercial algal blend containing Chlorella vulgaris Beij and Phaeodactylum tricornutum at a concentration of $1 \times 10^{4}$ cells mL $\mathrm{mL}^{-1}$ three times daily. The physico-chemical parameters, including $\mathrm{pH}_{\mathrm{NBS}}$, total dissolved inorganic carbon, temperature and salinity were measured every other day. Other related parameters of the carbonate system were calculated using the software CO2SYS (Lewis and Wallace, 1998). For CO2SYS settings, seawater pH constant was used the NBS scale from Millero et al. (2006). The information of the relevant water chemistry parameters is summarized in Table 1 .

After 28 days of cultivation, 14 individuals ( 8 for metabolomics analysis, and 6 for proteomic and enzymatic assay) were dissected

\section{Table 1}

Summary of seawater chemistry parameters during experimental exposures (mean \pm standard deviation). The $\mathrm{pH}$ was monitored daily with a $\mathrm{pH}$ electrode calibrated with NBS Standard pH solutions, and temperature, salinity, and total dissolved inorganic carbon (DIC) were determined every other day. $p \mathrm{CO}_{2}$ and total alkalinity (TA) were calculated from $\mathrm{pH}$ and DIC using CO2SYS software.

\begin{tabular}{lrr}
\hline \multicolumn{1}{l}{ Treatments } & \multicolumn{1}{c}{ Control } & OA stress \\
\cline { 1 - 1 } Parameters & & \\
\hline Temperature $\left({ }^{\circ} \mathrm{C}\right)$ & $17.98 \pm 0.97$ & $18.14 \pm 0.50$ \\
Salinity $(\% \circ)$ & $29.25 \pm 0.16$ & $29.41 \pm 0.08$ \\
$\mathrm{pH}(\mathrm{NBS} \mathrm{scale})$ & $8.18 \pm 0.01$ & $7.57 \pm 0.02$ \\
$\mathrm{DIC}(\mu \mathrm{mol} / \mathrm{kg})$ & $2143.13 \pm 26.21$ & $2377.30 \pm 25.20$ \\
$p \mathrm{PO}_{2}(\mathrm{ppm})$ & $427.53 \pm 10.14$ & $2013.41 \pm 71.22$ \\
$\mathrm{TA}(\mu \mathrm{mol} / \mathrm{kg})$ & $2352.86 \pm 29.65$ & $2369.24 \pm 28.92$ \\
\hline
\end{tabular}

immediately for the mantle tissues. The mantle tissues were flashfrozen in liquid nitrogen, and then stored at $-80^{\circ} \mathrm{C}$ prior to metabolomic and proteomic analysis, and enzymatic assay.

\subsection{Protein and metabolite extractions}

Total protein extraction was performed according to the method described by Lee and Lo (2008) with minor modifications (Wu et al., 2013a). Briefly, $100 \mathrm{mg}$ of mantle tissue was homogenized with $1 \mathrm{~mL}$ of ice-cold TRIzol reagent (Invitrogen, Carlsbad, CA, USA). After centrifugation (12000 $\mathrm{g}$ for $5 \mathrm{~min}$ at $4{ }^{\circ} \mathrm{C}$ ), the supernatant was added with $200 \mu \mathrm{L}$ of chloroform, shaken vigorously for $3 \mathrm{~min}$ and precipitated for $3 \mathrm{~min}$. After centrifugation ( $12000 \mathrm{~g}$ for $15 \mathrm{~min}$ at $4{ }^{\circ} \mathrm{C}$ ), the pellet obtained was precipitated with $750 \mu \mathrm{L}$ of isopropanol, washed with $1 \mathrm{~mL}$ of ethanol $(v / v 95 \%)$ and then centrifuged at $14000 \mathrm{~g}$ for $10 \mathrm{~min}$ at $4{ }^{\circ} \mathrm{C}$. The protein pellets were solubilized in the lysis buffer ( $7 \mathrm{M}$ urea; $2 \mathrm{M}$ thiourea; 4\% m/V CHAPS; $65 \mathrm{mM}$ DDT and 0.2\% W/V Bio-lyte buffer), and then incubated for $2 \mathrm{~h}$ at room temperature. The homogenate was centrifuged at $20000 \mathrm{~g}$ for $30 \mathrm{~min}$ and the supernatant was subjected to electrophoresis analysis. Protein concentrations were determined by Coomassie (Bradford) Protein Assay Kit (TianGen, China).

Metabolites in the tissue of mantle were extracted by the method described previously (Zhang et al., 2011). Briefly, $100 \mathrm{mg}$ of mantle tissue was crushed to a fine powder, and extracted with $400 \mu \mathrm{L}$ of methanol and $85 \mu \mathrm{L}$ of water. An aliquot of $440 \mu \mathrm{L}$ of water and $200 \mu \mathrm{L}$ of chloroform was added, and the sample was then centrifuged for $5 \mathrm{~min}$ at $3000 \mathrm{~g}$ to separate organic and aqueous layers. The methanol/water layer with polar metabolites was transferred to a glass vial. The samples were dried using a centrifugal concentrator (SPD111V230, Thermo Fisher Scientific, USA), and re-suspended in $600 \mu \mathrm{L}$ of phosphate buffer ( $100 \mathrm{mM} \mathrm{Na}_{2} \mathrm{HPO}_{4}$ and $\mathrm{NaH}_{2} \mathrm{PO}_{4}$, including $0.5 \mathrm{mM}$ TSP, $\mathrm{pH} 7.0$ ) in $\mathrm{D}_{2} \mathrm{O}$. The mixture was vortexed and centrifuged at $3000 \mathrm{~g}$ for $5 \mathrm{~min}$ at $4{ }^{\circ} \mathrm{C}$. The resultant supernatant substance $(550 \mu \mathrm{L})$ was then utilized for NMR analysis.

\section{3. ${ }^{1} \mathrm{H}$ NMR spectroscopy and multivariate data analysis}

Metabolite extracts of oyster mantle tissues were analyzed on a Bruker AV 500 NMR spectrometer as described previously (Zhang et al., 2011). The polar metabolites were analyzed using one-dimensional ${ }^{1} \mathrm{H}$ NMR and performed at $500.18 \mathrm{MHz}$ (at $298 \mathrm{~K}$ ). All ${ }^{1} \mathrm{H}$ NMR spectra were phased, baseline-corrected, and calibrated (internal reference: TSP at $0.0 \mathrm{ppm}$ ) manually using TopSpin (version 2.1, Bruker), the chemical shifts were analyzed by Chenomx Suite (Evaluation Version, Chenomx Inc., Canada), to accomplish the identification of the metabolites. All one dimensional ${ }^{1} \mathrm{H}$ NMR spectra were converted to a format for multivariate analysis using custom-written ProMetab software in Matlab (version 7.0; The MathsWorks, Natick, MA). Each ${ }^{1} \mathrm{H}$ NMR spectrum was segmented into $0.005 \mathrm{ppm}$ bins between 0.2 and $10.0 \mathrm{ppm}$ and excluded the bins of residual water ( 4.72 to $4.96 \mathrm{ppm}$ ). The total spectral area of the remaining bins was normalized to unity to facilitate the comparison between the spectra. All the NMR spectra were generalized log transformed with transformation parameter $\lambda=2 \times 10^{-8}$ to stabilize the variance across the spectral bins (Wu et al., 2013b).

Multivariate data analysis was performed with the software SIMCA-P + (V11.0, Umetrics, Sweden), as described previously (Feng et al., 2013; Ji et al., 2013a). The unsupervised pattern recognition method, principal component analysis (PCA) was used to reduce the dimensionality of the data and summarize the similarities and differences between multiple NMR spectra (Xu, 2004). Furthermore, the supervised multivariate data analysis methods, partial least squares discriminant analysis (PLS-DA) and orthogonal projection to latent structure with discriminant analysis (O-PLS-DA) were sequentially carried out to uncover and extract the statistically significant alterations of metabolites related to elevated $p \mathrm{CO}_{2}$ in 
oyster mantle tissues; the details were described previously (Ji et al., 2013b).

\subsection{Two-dimensional gel electrophoresis and image analysis}

For the isoelectric focusing (IEF), $130 \mu \mathrm{g}$ of protein was loaded onto IPG strips with a linear pH gradient from 3 to 10 (Immobiline Drystrip ${ }^{\mathrm{TM}}$ $24 \mathrm{~cm}$, GE Healthcare, USA). Isoelectric focusing was conducted using the following protocol: $30 \mathrm{~V}$ for $12 \mathrm{~h}, 100 \mathrm{~V}$ for $5 \mathrm{~h}, 500 \mathrm{~V}$ for $1 \mathrm{~h}, 1000 \mathrm{~V}$ for $1 \mathrm{~h}$, and a linear increase of voltage to $8000 \mathrm{~V}$ for $11 \mathrm{~h}$ (Ettan IPGphor 3 , GE Healthcare, USA). After the first dimension, the IPG strips were incubated for $15 \mathrm{~min}$ in equilibration buffer $(0.05 \mathrm{M}$ Tris-HCl, $\mathrm{pH} 8.8$; $6 \mathrm{M}$ urea; $30 \%$ glycerol; $2 \% w / v$ SDS and $1 \% w / v$ DTT) followed by $15 \mathrm{~min}$ in equilibration buffer containing $2.5 \%(w / v)$ iodoacetamide (O'farrell, 1975). The equilibrated IPGs were separated on 12.5\% SDSPAGE gels using Ettan DALTsix system. After electrophoresis, the gels were silver stained following the methods of Gharahdaghi et al. (1999) and Mortz et al. (2001). The resulting gels were captured with ImageScanner III and analyzed by ImageMaster 2D Platinum software (Version7.0, GE Healthcare, USA). All detected spots were manually checked and artifact spots were removed. The abundance of each spot was calculated by the percentage volume (\% vol). Only protein spots with significant changes $(>1.5$ folds and $p<0.05)$ were considered as differentially expressed ones. Triple biological replicates ( 2 individuals pooled into 1 sample) were run for each treatment.

\subsection{Mass spectrometry analysis}

Selected spots were excised manually, and digested according to the protocol from Katayama et al. (2001). Gel pieces were first washed in $25 \mathrm{mM} \mathrm{NH}_{4} \mathrm{HCO}_{3}$ in $50 \% \mathrm{v} / \mathrm{v}$ acetonitrile, and then dehydrated in $100 \%$ acetonitrile. After that, gel pieces were vacuum-dried, and rehydrated

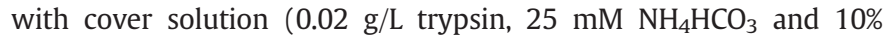
acetonitrile), and incubated overnight at $37{ }^{\circ} \mathrm{C}$. The resulting peptide mixture was re-suspended with $5 \mu \mathrm{L}$ of $0.1 \%$ TFA followed by mixing in $1: 1$ ratio with a saturated solution of $\alpha$-cyano-4-hydroxy-trans-cinnamic acid in 50\% acetonitrile (Shevchenko et al., 1996). One milliliter of mixtures was analyzed by an ABI 4800 MALDI-TOF/TOF Plus mass spectrometer (Applied Biosystems, Foster City, USA). Data were acquired in a positive MS reflector using a CalMix5 standard to calibrate the instrument (ABI4800 Calibration Mixture, Foster City, USA). Both the MS and MS/MS data were integrated and processed by using the GPS Explorer V3.6 software (Applied Biosystems, Foster City, USA) with default parameters. Proteins were successfully identified based on $95 \%$ or higher confidence interval of their scores in the MASCOT V2.4 search engine (Matrix Science Ltd., London, U.K.). The following parameters were used in the search: NCBInr Metazoa (Animals) (2861494 sequences) database; trypsin as the digestion enzyme; one missed cleavage site; partial modifications of cysteine carbamidomethylation and methionine oxidization; no fixed modifications; 0.15 Da for precursor ion tolerance and $0.25 \mathrm{Da}$ for fragment ion tolerance. Individual ions scores $>40$ indicated identity or extensive homology $(p<0.05)$. Only proteins whose MASCOT scores (http://www.matrixscience.com) greater than the significance threshold were discussed.

\subsection{Enzyme activities and calcium concentration}

The mantle samples of six individuals from each treatment were homogenized $(1: 10, w / v)$ in an ice-cold lysis buffer $(0.01 \mathrm{mM}$ Tris; $0.0001 \mathrm{mM}$ EDTA-2Na; $0.01 \mathrm{mM}$ sucrose and $0.8 \% \mathrm{NaCl}, \mathrm{pH} 7.4)$, and then subjected to enzyme activity and calcium ion $\left(\mathrm{Ca}^{2+}\right)$ concentration assays. Measurement of alkaline phosphatase (AKP, EC 3.1.3.1) and total adenosinetriphosphatase (Total ATPase) was performed by using commercial enzyme kits (Nanjing Jiancheng Bioengineering Institute, PR China). $\mathrm{Ca}^{2+}$ content was determined by the methylthymolblue method using a commercial kit (Nanjing Jiancheng Bioengineering Institute, PR China).

Protein concentration was determined with Bradford method by using bovine serum albumin as standard (Bradford, 1976). The enzyme activities and $\mathrm{Ca}^{2+}$ concentration were expressed as $\mathrm{U} / \mathrm{mg}$ protein and $\mathrm{nmol} / \mathrm{mg}$ protein, respectively.

\subsection{Histological analysis}

Histological analysis of oyster mantle tissues was performed according to the protocol from Al-Subiai et al. (2011). Briefly, after elevated $p \mathrm{CO}_{2}$ exposure, the mantle tissues were dissected and fixed in Bonn's liquid (saturated picric acid/formaldehyde/glacial acetic acid $=15 / 5 / 1 ; v / v / v$ ) for more than $24 \mathrm{~h}$, dehydrated through graded alcohol series, and then embedded in paraffin. Sections were cut at $7 \mu \mathrm{m}$ and stained with hematoxylin and eosin (H.E.) on a LST94 Linear Slide Stainer (Hestion, Australia). Slides were examined under an Olympus light microscope for routine histology and morphometrics, and histological measurements were taken using an ocular micrometer.

\subsection{RNA extraction and quantitative real-time PCR}

The details of RNA extraction and qRT-PCR were described in the Supporting Information. All primers used in this assay were listed in Table S1.

\section{Result and discussion}

3.1. Effects of elevated $\mathrm{pCO}_{2}$ exposure on enzyme activities, $\mathrm{Ca}^{2+}$ content and histopathology of oyster mantles

Alkaline phosphatase (AKP) is a hydrolase enzyme responsible for removing phosphate groups from many types of molecules. It has been found in a broad variety of biomineralizing tissues. Moreover, the participation of AKP in the calcification process has been confirmed for mollusks (Kakoi et al., 2008; Hohagen and Jackson, 2013). ATPases play an important role in the maintenance of cell permeability and energy transformation in the biological system. These ATPases have been classified as F-, V-, A-, P- and E-ATPases based on functional differences. They all catalyze the reaction of ATP synthesis and/or hydrolysis (Pedersen and Carafoli, 1987). Previous research reported that elevated $p \mathrm{CO}_{2}$ could affect energy metabolism of $C$. gigas (Lannig et al., 2010). However, no significant changes in AKP and total ATPase activities were found between control and the elevated $\mathrm{pCO}_{2}$-exposed group (Table 2).

$\mathrm{Ca}^{2+}$ is not only the primary cation participating in the formation of shell structures, but also a regulatory agent involved in many physiological processes of mollusks (Morse et al., 2006). It is generally accepted that seawater acidification resulted in dissolution of calcium carbonate minerals, which perhaps affected many physiological processes of the mantle tissue in mollusks (Navarro et al., 2013). In the present study, $\mathrm{Ca}^{2+}$ content was significantly $(p<0.05)$ decreased in the mantle of elevated $p \mathrm{CO}_{2}$-exposed oysters (Table 2 ). Previous researches have demonstrated that the deposition of calcium in the shell is regulated

Table 2

The biochemical indices including AKP, total ATPase activities and $\mathrm{Ca}^{2+}$ content in mantle tissue of $C$. gigas exposed to elevated $\mathrm{pCO}_{2}$.

\begin{tabular}{lcc}
\hline Biochemical indices $^{\mathrm{a}}$ & \multicolumn{1}{c}{ Control } & OA stress \\
\hline AKP & $14.71 \pm 7.31$ & $19.61 \pm 5.63$ \\
Total ATPase & $9.78 \pm 3.77$ & $10.02 \pm 2.45$ \\
$\mathrm{Ca}^{2+}$ content & $0.57 \pm 0.11$ & $0.40 \pm 0.08$ \\
\hline
\end{tabular}

a The enzyme activities and $\mathrm{Ca}^{2+}$ content were expressed as $\mathrm{U} / \mathrm{mg}$ protein and $\mathrm{nmol} /$ mg protein, respectively.

* Statistical significances between control and elevated $\mathrm{pCO}_{2}$-exposed group were less than 0.05 . 
by the mollusks mantle (Istin and Girard, 1970). Macromolecules and the ions (including $\mathrm{Ca}^{2+}$, bicarbonate) necessary for mineralization were secreted into the extrapallial fluid by the mantle cells (Addadi et al., 2006). The decreased $\mathrm{Ca}^{2+}$ level in the mantle tissue of oysters perhaps indicated a reduced level of mineralization under acidification. It is postulated that decreased oceanic $\mathrm{pH}$ could destabilize the acidbase regulation, and the uptake, accumulation and transport of $\mathrm{Ca}^{2+}$ in mantle tissue, consequently perhaps leading to the reduced calcium availability in mantle.

As concerned to histological analysis, no significant tissue damage was observed in mantle tissue of oyster $C$. gigas (data not shown), which suggested that the elevated $p \mathrm{CO}_{2}$ exposure perhaps did not cause changes in the histological morphology of oyster mantles.

\subsection{Effects of elevated $\mathrm{pCO}_{2}$ exposure on metabolome of oyster mantles}

The representative ${ }^{1} \mathrm{H}$ NMR spectra of mantle tissue extracts from control and elevated $p \mathrm{CO}_{2}$ groups are presented in Fig. 1. Several metabolite classes were identified, including amino acids (leucine, valine, threonine, alanine, arginine, glutamate, aspartate, lysine, glycine, tyrosine and histidine etc.), organic osmolytes (hypotaurine, dimethylglycine, taurine, betaine and homarine), intermediates in the Krebs cycle and energy metabolism-related metabolites (succinate, fumarate and ATP).

Principal component analysis (PCA) was performed on the NMR spectral datasets of mantle extracts from control $(\mathrm{pH} \mathrm{8.2)}$ and $\mathrm{pH}$ 7.6 treated groups. PCA results showed that there was a significant $(p<0.01)$ separation between control and $\mathrm{pH} 7.6$ exposed groups (data not shown). Further O-PLS-DA was performed on the NMR spectral data to seek the metabolic biomarkers induced by elevated $\mathrm{pCO}_{2}$ (Fig. 2). Clearly, the concentrations of ATP, succinate, amino acids including arginine and lysine were significantly $(p<0.05)$ increased in elevated $p \mathrm{CO}_{2}$ treated oysters, while the concentrations of glutamate and glutamine were decreased.

Free amino acids were previously found to balance intracellular osmolarity and energy metabolism by marine mollusks (Viant et al., 2003). In our case, the elevated lysine and arginine, and reduced glutamate and glutamine probably meant that oysters could use free amino acids to regulate osmolarity in mantles under elevated $p \mathrm{CO}_{2}$ exposure. In addition, the decrease of glutamate and glutamine might be related to the neurotoxic effects induced by elevated $p \mathrm{CO}_{2}$ exposure in oyster. The increased levels of ATP and succinate were the indicators of disturbed energy metabolism (Ji et al., 2013c). The elevated ATP was probably mobilized to compensate for the energy consumption during

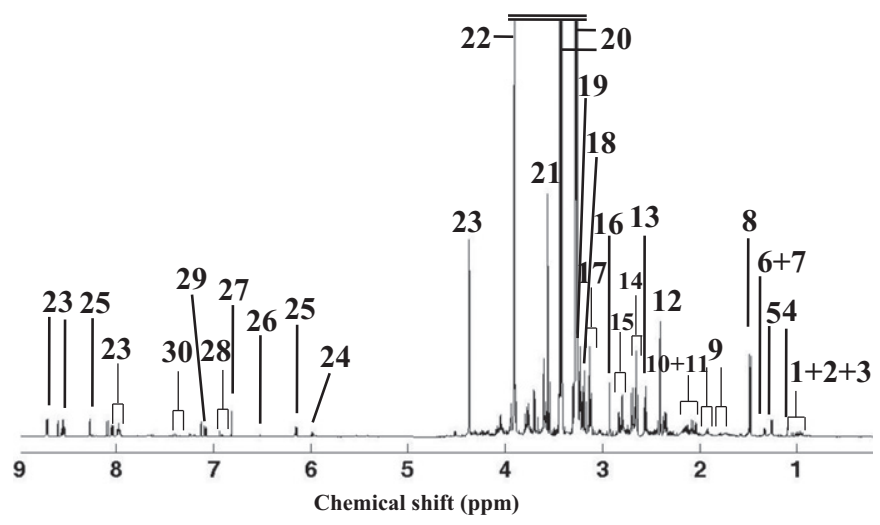

Fig. 1. A representative 1-dimensional $500 \mathrm{MHz}{ }^{1} \mathrm{H}$ NMR spectrum of mantle tissue extracts from control oyster $C$. gigas. Keys: (1) leucine, (2) isoleucine, (3) valine, (4) unknown 1 (1.10 ppm), (5) 3-aminobutyrate (6) lactate, (7) threonine, (8) alanine, (9) arginine, (10) glutamate, (11) glutamine, (12) succinate, (13) $\beta$-alanine, (14) hypotaurine, (15) aspartate, (16) dimethylglycine, (17) lysine, (18) choline, (19) phosphocholine, (20) taurine, (21) glycine, (22) betaine, (23) homarine, (24) unknown 2 (5.98 ppm), (25) ATP, (26) fumarate, (27) unknown 3 (7.68 ppm), (28) tyrosine (29) histidine and (30) phenylalanine.
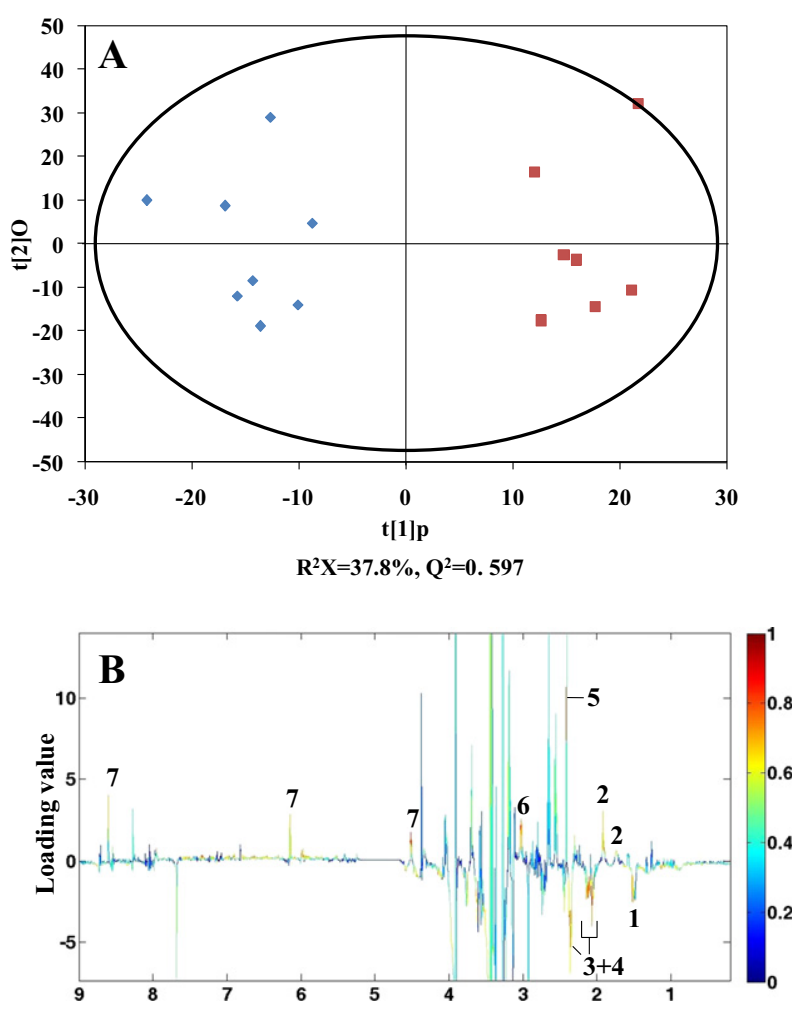

Fig. 2. OPLS-DA scores plot derived from ${ }^{1} \mathrm{H}$ NMR spectra of oyster mantle tissue extracts from the control $(\checkmark)$ and elevated $p \mathrm{CO}_{2}$-exposed oyster groups $(\mathbf{\square}),(\mathrm{A})$ and corresponding coefficient plot (B). The color map shows the significance of metabolite variations between the two classes (control and elevated $p \mathrm{CO}_{2}$ exposure). Peaks in the positive direction indicate metabolites that are more abundant in the elevated $p \mathrm{CO}_{2}$-exposed group. Consequently, metabolites that are more abundant in the control group are presented as peaks in the negative direction. Keys: (1) unknown (1.52 ppm), (2) arginine, (3) glutamate, (4) glutamine, (5) succinate, (6) lysine and (7) ATP.

elevated $p \mathrm{CO}_{2}$ exposure, which suggested that elevated $p \mathrm{CO}_{2}$ exposure caused disturbance in energy metabolism of oyster mantles. Recent studies have suggested that elevated $p \mathrm{CO}_{2}$ exposure could cause the alteration of energy budgets in a variety of mollusks. For example, seawater acidification led to disruption of energy metabolism and resulted in higher standard metabolic rates in juvenile oyster C. virginica (Beniash et al., 2010; Dickinson et al., 2012). Succinate was an intermediate in Krebs cycle involved in cellular energy metabolism. The elevated succinate was also observed in mantle tissue from mussel $M$. edulis and oyster $C$. gigas exposed to elevated $\mathrm{pCO}_{2}$ (Lannig et al., 2010; Ellis et al., 2014). A previous study suggested that the concentrations of succinate in mantle tissue of $C$. gigas showed a close correlation with $\mathrm{H}^{+}$accumulation (Michaelidis et al., 2005), Therefore, the increase of succinate might be a bioindicator of the mantle tissue of oysters responded to OA stress.

\subsection{Effects of elevated $\mathrm{pCO}_{2}$ exposure on the proteome of oyster mantle}

A comparative proteomics study was conducted to identify molecular mechanisms shaping the physiological processes in mantle tissue from the control and elevated $p \mathrm{CO}_{2}$ exposed group. Analysis of 2-DE gels using ImageMaster 2D Platinum 7.0 software resulted in identification of 1386 reproducible protein spots between these two treatments. Only those spots that showed consistent variation and more than 1.5 -fold change in abundance were accepted for further analysis. Consequently, a total of 44 protein spots showed significant change in abundance in response to elevated $p \mathrm{CO}_{2}$. Among them, 18 were down-regulated and 26 were up-regulated. Due to limited protein sequence information, only 11 proteins were successfully identified with high confidences. Spots significantly altered in abundance were indicated in Fig. 3, 
including 9 up-regulated and 2 down-regulated proteins. The details of identified proteins including their protein names, accession numbers and additional MS data were summarized in Table 3. The relative abundance of individual protein identified in mantles was shown in Fig. S1.

The functional properties of these identified proteins were classified by searching against the Uniprot (http://www.uniprot.org/) and Cluster of Orthologous Groups of proteins (COGs). These proteins were found to be mainly involved in energy metabolism (aldehyde dehydrogenase, malate dehydrogenase and phosphoenolpyruvate carboxykinase) and cytoskeleton function (myosin regulatory light chain A, myosin essential light chain, myosin catalytic light chain LC-1, calponin-2, non-neuronal cytoplasmic intermediate filament protein, tropomyosins and tropomyosin 1 ).

The integrated proteomic and metabolomic responses in mantles from $C$. gigas under elevated $\mathrm{pCO}_{2}$ exposure were summarized in Fig. S3 according to Kyoto Encyclopedia of Genes and Genomes (http://www.genome.jp/kegg/) and Uniprot database. Malate dehydrogenase (EC 1.1.1.37, MDH) is an enzyme that reversibly catalyzes the oxidation of malate to oxaloacetate using the reduction of NAD to $\mathrm{NADH}$. There exist two main isoforms of MDH in eukaryotic cells. One is found in the mitochondrial matrix, participating as a key enzyme in the citric acid cycle. The other is found in the cytoplasm, assisting the malate-aspartate shuttle with exchanging reducing equivalents so that malate can pass through the mitochondrial membrane to be transformed into oxaloacetate for further cellular processes (Chapman et al., 1999;

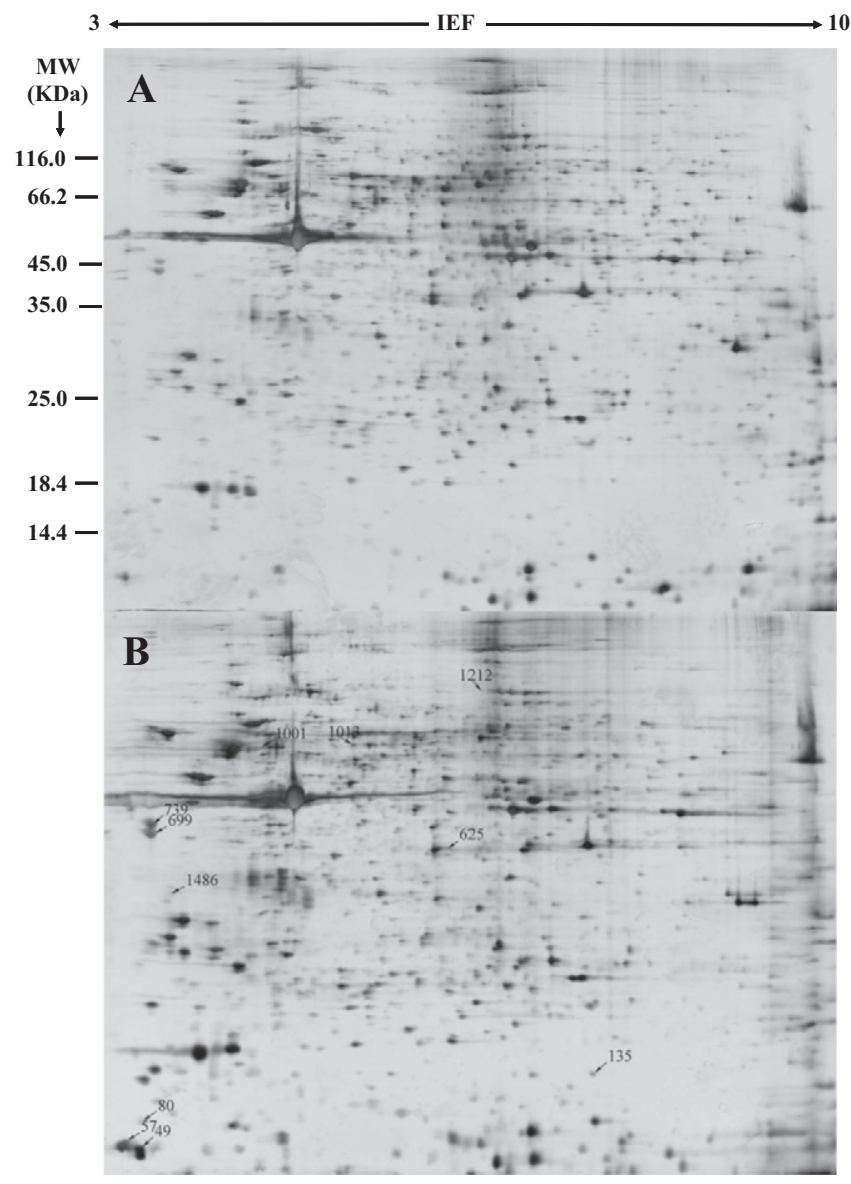

Fig. 3. Representative 2-D gels of proteins extracted from mantles of $C$. gigas. First dimension was performed using $130 \mu \mathrm{g}$ total soluble proteins on linear gradient IPG strips with $\mathrm{pH} 3-10$. In the second dimension, 12.5\% SDS-PAGE gels were used and proteins were visualized using silver staining. (A) The control group. (B) The elevated $p \mathrm{CO}_{2}$ exposed group. Arrows show 11 protein spots that change significantly from elevated $p \mathrm{CO}_{2}$ exposed group compared to the control group.
Minárik et al., 2002). The up-regulation of MDH (cytoplasmic isoform) suggested that elevated $p \mathrm{CO}_{2}$ exposure perhaps affected exchange of substrates in the energy metabolism of mantle tissue.

Aldehyde dehydrogenase (EC 1.2.1.10, ALDH) is an enzyme that catalyzes the oxidation of acetaldehyde to acetate during ethanol metabolism (Sydow et al., 2004). Previous studies have found that ALDH was suppressed in gills and digestive glands of clam Ruditapes decussates and mussel $M$. edulis under marine pollutants exposure, respectively (Apraiz et al., 2006; Chora et al., 2009). ALDH has been used as a biochemical marker to evaluate the biological responses of mussel M. galloprovincialis to natural and anthropic stresses (Nesto et al., 2004). In the present study, down-regulated ALDH suggested potential metabolic change in mantle tissue under elevated $\mathrm{pCO}_{2}$ exposure.

Phosphoenolpyruvate carboxykinase (EC 4.1.1.31, PEPCK) catalyzes the rate-limiting step in gluconeogenesis (Hanson and Garber, 1972), namely the reversible decarboxylation of oxaloacetate to phosphoenolpyruvate (PEP). Pyruvate kinase could convert PEP to pyruvate which is a substrate in the Krebs cycle. Moreover, PEP would become mainly a substrate for PEPCK when the metabolic pathway switched by several mechanisms, leading to the formation of succinate. In oyster $C$. gigas under hypoxic exposure, the late induction of PEPCK gene expression and enzyme activity followed by an accumulation of succinate indicated the switch from the aerobic to the anaerobic metabolic pathway (Moullac et al., 2007). In the present study, the down-regulation of PEPCK perhaps suggested the alternation of energy production under elevated $\mathrm{pCO}_{2}$ exposure in oyster mantles. The inference was validated by the increased levels of ATP and succinate detected by metabolomic analysis. The shift in energy metabolism has been confirmed in a variety of mollusks responded to stresses caused by both abiotic and biotic factors (Cherkasov et al., 2006; Wu et al., 2013c). Generally, aerobic energy metabolism was down-regulated in response to OA stress, hypoxia and hyposalinity, but other metabolic pathways were activated to switch metabolic fuels or to counteract increased oxidative stress (Timmins-Schiffman et al., 2014; Tomanek, 2014).

The cytoskeleton is considered as an important, complex, and dynamic cell component in mediating cell migration or division, determination of cell shape, redistribution of plasma membrane components, endocytosis, exocytosis, intracellular movement, organization of organelles, and formation of intercellular junctions (Weber et al., 1989). The cytoplasmic intermediate filaments (IF) comprise many distinct members, which are responsible for the spatial organization of the cytoskeleton in most cells (Dodemont et al., 1990). Calponin is an actin-, tropomyosin- and calmodulin- binding protein that has been suggested to be involved in the $\mathrm{Ca}^{2+}$-dependent regulation of smooth muscle contraction (Haeberle, 1994). It inhibits actin-activated myosin ATPase activity and actin-myosin interaction by phosphorylation/dephosphorylation (Winder and Walsh, 1993; Winder et al., 1993). Calponin may also regulate the pool of free actin available for cytoskeleton organization by anchoring myosin to actin (Szymanski and Tao, 1993). Tropomyosin, a well-characterized regulator of muscle contraction, existed in muscle and non-muscle cells (Itoh and Fujinoki, 2008). It could associate with troponin complex and function as a co-regulator of actin-myosin interaction in $C$. gigas (Fujinoki et al., 2006). Myosin regulatory light chains also play a crucial role in regulating actin-myosin interaction. The increase of tropomyosin and myosin abundances were previously observed in Sydney rock oyster $\mathrm{S}$. glomerata exposed to $\mathrm{Pb}$ and $\mathrm{Cu}$ contamination (Thompson et al., 2011, 2012). Similarly, exposure of eastern oyster C. virginica to elevated $\mathrm{pCO}_{2}$ resulted in variation in the abundance of cytoskeleton-related proteins, such as actin, actin-polymerization factor and calponin 2 in the mantle tissue (Tomanek et al., 2011). A previous study has suggested that the proteome of mollusks in response to environmental stress could always provoke the alterations in cytoskeleton related proteins (Artigaud et al., 2014). Moreover, environmental stresses often lead to induction of 
Table 3

Summary, identification, and quantitative results of proteins differentially expressed in response to elevated $p \mathrm{CO}_{2}$ exposure (approx. pH 7.6, $p \mathrm{CO}_{2} 2013$ ppm).

\begin{tabular}{|c|c|c|c|c|c|c|c|c|c|}
\hline \multirow[t]{2}{*}{ Spot no. ${ }^{\mathrm{a}}$} & \multirow[t]{2}{*}{ Category and name } & \multirow[t]{2}{*}{ Species } & \multirow[t]{2}{*}{ gi number ${ }^{b}$} & \multirow[t]{2}{*}{ Thero $\mathrm{pl} / \mathrm{kDa}^{\mathrm{c}}$} & \multirow[t]{2}{*}{ Score $^{\mathrm{d}}$} & \multirow[t]{2}{*}{$\mathrm{SC}(\%)^{\mathrm{e}}$} & \multirow[t]{2}{*}{$\mathrm{PN}^{\mathrm{f}}$} & \multicolumn{2}{|c|}{$\begin{array}{l}\mathrm{OA} \\
\text { stress/control }^{\mathrm{g}}\end{array}$} \\
\hline & & & & & & & & Ratio & $P$ \\
\hline 49 & Myosin regulatory light chain A, smooth adductor muscle & Crassostrea gigas & gi|405952510 & $4.38 / 14.61$ & 209 & 26 & 4 & 1.58 & 0.043 \\
\hline 57 & Myosin essential light chain & Crassostrea gigas & gi|40642994 & $4.53 / 18.27$ & 532 & 30 & 6 & 2.91 & 0.013 \\
\hline 80 & Myosin catalytic light chain LC-1, mantle muscle & Crassostrea gigas & gi|405952901 & $4.49 / 18.62$ & 456 & 33 & 8 & 1.55 & 0.013 \\
\hline 135 & Calponin-2 & Crassostrea gigas & gi|405975242 & $6.84 / 43.46$ & 638 & 29 & 10 & 1.64 & 0.042 \\
\hline 625 & Malate dehydrogenase, cytoplasmic, partial & Crassostrea gigas & gi|405959090 & $6.18 / 36.54$ & 534 & 24 & 5 & 2.25 & 0.012 \\
\hline 699 & Tropomyosin & Crassostrea gigas & gi|219806594 & $4.57 / 33.06$ & 744 & 29 & 8 & 1.53 & 0.003 \\
\hline 739 & Tropomyosin & Crassostrea gigas & gi|15419048 & $4.49 / 26.91$ & 700 & 32 & 7 & 2.13 & 0.001 \\
\hline 1001 & Non-neuronal cytoplasmic intermediate filament protein & Crassostrea gigas & gi|405950795 & $5.38 / 69.65$ & 783 & 15 & 7 & 2.81 & 0.047 \\
\hline 1013 & Aldehyde dehydrogenase, mitochondrial & Crassostrea gigas & gi|405965075 & $6.18 / 57.56$ & 403 & 13 & 6 & -2.04 & 0.001 \\
\hline 1212 & Phosphoenolpyruvate carboxykinase & Crassostrea gigas & gi|113207854 & $6.51 / 72.28$ & 88 & 2 & 1 & -2.01 & 0.045 \\
\hline 1486 & Tropomyosin 1, partial & Ostrea edulis & gi|375073719 & $4.80 / 16.32$ & 173 & 23 & 2 & 5.11 & 0.027 \\
\hline
\end{tabular}

a Spot ID as assigned in Fig. 2.

b Database GI numbers after searching against the NCBInr database.

c The theoretical MW and $\mathrm{pI}$ of the identified proteins.

d Mascot protein score reported.

e Sequences coverage (\%).

f Number of matched peptide sequence.

g Fold changes with significant changes $(>1.5$ folds and $p<0.05)$ were calculated using ImageMaster 2D Platinum 7.0.

adaptive responses in addition to the cellular stress response, which aimed at stabilizing macromolecular structure and function during adverse, abnormal or pathological conditions, and at conserving metabolic energy for homeostatic adaptations (Kultz, 2003, 2005). In this study, non-neuronal cytoplasmic intermediate filament, calponin-2, three types of tropomyosins and myosins were significantly up-regulated under elevated $p \mathrm{CO}_{2}$ exposure, indicating that elevated $p \mathrm{CO}_{2}$ could impair the motility and organization of cytoskeleton in oyster mantles. The shift in metabolic pathways and cytoskeleton function is perhaps directed at re-establishing cellular homeostasis with regard to the elevated $\mathrm{pCO}_{2}$ conditions.

\subsection{Correlation between mRNA and protein abundance}

Ten representative genes related to oyster shell formation (CgPif97, Cgigas-IMSP-2, Cgigas-IMSP-3, hypothetical protein CGI_10007458 (CA1), and carbonic anhydrase 6 (CA6)) and the altered proteins under elevated $p \mathrm{CO}_{2}$ exposure (myosin essential light chain, calponin-2, tropomyosin, MDH and ALDH) were selected for transcript analysis to validate the proteomics analysis. No significant alteration in the expression level of these genes was observed between the control and the elevated $p \mathrm{CO}_{2}$ exposed group with the exception of $\mathrm{MDH}$ and CA 6 (Fig. S2). The enzyme carbonic anhydrase has been discovered in the shell-forming mantle tissue of a large number of mollusks, and contributes to the formation of $\mathrm{CaCO}_{3}$ skeletons (Henry, 1996). In sea urchin S. purpuratus larvae, the expression of carbonic anhydrase gene was also upregulated under high $\mathrm{CO}_{2}$ exposure (Todgham and Hofmann, 2009). The increased expression of CA6 under high $p \mathrm{CO}_{2}$ exposure perhaps suggested that $\mathrm{OA}$ could influence the calcification process and $\mathrm{pH}$ homeostasis in oyster. However, the alteration of MDH protein was not coincident with MDH gene expression, and no significant change of the expression level of most selected genes was observed under elevated $p \mathrm{CO}_{2}$ exposure. The disparity between changes in gene expression and corresponding protein abundance has been reported in numerous previous reports (Glanemann et al., 2003; Wang et al., 2010). It was speculated that the minimal and/or limited correlations between mRNA and protein expression levels were probably due to the posttranscriptional and posttranslational modifications, and also related to the differential degradation rates between mRNA and protein (Vogel and Marcotte, 2012).

\section{Conclusions}

In summary, the molecular responses induced by elevated $\mathrm{pCO}_{2}$ were investigated at metabolite and protein levels in the mantle tissue of oyster $C$. gigas. The metabolic and proteomic biomarkers suggested that elevated $\mathrm{pCO}_{2}$ exposure could induce disturbances in energy metabolism and cytoskeleton dysfunction in oyster mantles. This study demonstrated that integrated analysis of metabolomics and proteomics could provide important insights into the effects of $\mathrm{OA}$ at molecular levels.

\section{Acknowledgments}

This research was supported by the National Natural Science Foundation of China (No. 31172388), the Key Research Program of the Chinese Academy of Sciences (Grant No. KZZD-EW-14) and the Zhejiang Provincial Top Key Discipline of Aquaculture Open Foundation (XKZSC1402). We thank Prof. Mark Viant for the use of ProMetab software.

\section{Appendix A. Supplementary data}

The following are the supplementary materials related to this article. Supplementary data associated with this article can be found, in the online version, at http://dx.doi.org/10.1016/j.cbd.2014.12.001.

\section{References}

Addadi, L., Joester, D., Nudelman, F., Weiner, S., 2006. Mollusk shell formation: a source of new concepts for understanding biomineralization processes. Chem. A Eur. J. 12, 980-987.

Al-Subiai, S.N., Moody, A.J., Mustafa, S.A., Jha, A.N., 2011. A multiple biomarker approach to investigate the effects of copper on the marine bivalve mollusc, Mytilus edulis. Ecotoxicol. Environ. Saf. 74, 1913-1920.

Apraiz, I., Mi, J., Cristobal, S., 2006. Identification of proteomic signatures of exposure to marine pollutants in mussels (Mytilus edulis). Mol. Cell. Proteomics 5, 1274-1285.

Artigaud, S., Lavaud, R., Thébault, J., Jean, F., Strand, Ø., Strohmeier, T., Milan, M., Pichereau, V., 2014. Proteomic-based comparison between populations of the GreatScallop, Pecten maximus. J. Proteome 105, 164-173.

Beniash, E. Ivanina, A., Lieb, S.N., Kurochkin, I., Sokolova, I.M., 2010. Elevated level of carbon dioxide affects metabolism and shell formation in oysters Crassostrea virginica. Mar. Ecol. Prog. Ser. 419, 95-108.

Bradford, M., 1976. A rapid and sensitive method for the quantification of microgram quantities of protein utilizing the principle of protein-dye binding. Anal. Biochem. $72,248-254$

Caldeira, K., Wickett, M.E., 2003. Anthropogenic carbon and ocean pH. Nature 425, 365.

Chapman, A.D.M., Cortes, A., Dafforn, T.R., Clarke, A.R., Brady, R.L., 1999. Structural basis of substrate specificity in malate dehydrogenases: crystal structure of a ternary complex of porcine cytoplasmic malate dehydrogenase, $\alpha$-ketomalonate and TetrahydoNAD. J. Mol. Biol. 285, 703-712.

Cherkasov, A.S., Biswas, P.K., Ridings, D.M., Ringwood, A.H., Sokolova, I.M., 2006. Effects of acclimation temperature and cadmium exposure on cellular energy budgets in the marine mollusk Crassostrea virginica: linking cellular and mitochondrial responses. J. Exp. Biol. 209, 1274-1284. 
Chora, S., Starita-Geribaldi, M., Guigonis, J.M., Samson, M., Romeo, M., Bebianno, M.J., 2009. Effect of cadmium in the clam Ruditapes decussatus assessed by proteomic analysis. Aquat. Toxicol. 94, 300-308.

Dickinson, G.H., Ivanina, A.V., Matoo, O.B., Pörtner, H.O., Lannig, G., Bock, C., Beniash, E., Sokolova, I.M., 2012. Interactive effects of salinity and elevated $\mathrm{CO}_{2}$ levels on juvenile eastern oysters, Crassostrea virginica. J. Exp. Biol. 215, 29-43.

Dineshram, R., Wong, K.K.W., Xiao, S., Ziniu Yu, Z., Qian, P.Y., Thiyagarajan, V., 2012. Analysis of Pacific oyster larval proteome and its response to high- $\mathrm{CO}_{2}$. Mar. Pollut. Bull. 64, 2160-2167.

Dodemont, H., Riemer, D., Weber, K., 1990. Structure of an invertebrate gene encoding cytoplasmic intermediate filament (If) proteins-implications for the origin and the diversification of If proteins. EMBO J. 9, 4083-4094.

Doney, S.C., Fabry, V.J., Feely, R.A., Kleypas, J.A., 2009. Ocean acidification: the other $\mathrm{CO}_{2}$ problem. Annu. Rev. Mar. Sci. 1, 169-192.

Ellis, R., John, I., Spicer, J., Byrne, J.J., Sommer, U., Viant, M., White, D.A., Widdicombe, S., 2014. ${ }^{1} \mathrm{H}$ NMR metabolomics reveals contrasting response by male and female mussels exposed to reduced seawater $\mathrm{pH}$, increased temperature, and a pathogen. Environ. Sci. Technol. 48, 7044-7052.

Evans, T.G., Chan, F., Menge, B.A., Hofmann, G.E., 2013. Transcriptomic responses to ocean acidification in larval sea urchins from a naturally variable $\mathrm{pH}$ environment. Mol. Ecol. 22, 1609-1625.

Feely, R.A., Sabine, C.L., Lee, K., Berelson, W., Kleypas, J., Fabry, V.J., Millero, F.J., 2004. Impact of anthropogenic $\mathrm{CO}_{2}$ on the $\mathrm{CaCO}_{3}$ system in the oceans. Science 305 362-366.

Feng, J., Li, J., Wu, H., Chen, Z., 2013. Metabolic responses of HeLa cells to silica nanoparticles by NMR-based metabolomic analyses. Metabolomics 9, 874-886.

Fujinoki, M., Ueda, M., Inoue, T., Yasukawa, N., Inoue, R., Ishimoda-Takagi, T., 2006. Heterogeneity and tissue specificity of tropomyosin isoforms from four species of bivalves. Comp. Biochem. Physiol. B Biochem. Mol. Biol. 143, 500-506.

Gazeau, F., Parker, L.M., Comeau, S., Gattuso, J.P., O'Connor, W.A., Martin, S., Portner, H.O., Ross, P.M., 2013. Impacts of ocean acidification on marine shelled molluscs. Mar. Biol. 160, 2207-2245.

Gharahdaghi, F., Weinberg, C.R., Meagher, D.A., Imai, B.S., Mische, S.M., 1999. Mass spectrometric identification of proteins from silver-stained polyacrylamide gel: a method for the removal of silver ions to enhance sensitivity. Electrophoresis 20, 601-605.

Glanemann, C., Loos, A., Gorret, N., Willis, L.B., O'Brien, X.M., Lessard, P.A., Sinskey, A.J., 2003. Disparity between changes in mRNA abundance and enzyme activity in Corynebacterium glutamicum: implications for DNA microarray analysis. Appl. Microbiol. Biotechnol. 61, 61-68.

Haeberle, J.R., 1994. Calponin decreases the rate of cross-bridge cycling and increases maximum force production by smooth-muscle myosin in an in-vitro motility assay. J. Biol. Chem. 269, 12424-12431.

Hanson, R.W., Garber, A.J., 1972. Phosphoenolpyruvate carboxykinase 1 its role in gluconeogenesis. Am. J. Clin. Nutr. 25, 1010-1021.

Henry, R.P., 1996. Multiple roles of carbonic anhydrase in cellular transport and metabolism. Annu. Rev. Physiol. 58, 523-538.

Higuera-Ruiz, R., Elorza, J., 2009. Biometric, microstructural, and high-resolution trace element studies in Crassostrea gigas of Cantabria (Bay of Biscay, Spain): anthropogenic and seasonal influences. Estuar. Coast. Shelf Sci. 82, 201-213.

Hohagen, J., Jackson, D.J., 2013. An ancient process in a modern mollusc: early development of the shell in Lymnaea stagnalis. BMC Dev. Biol. 13, 27.

Hönisch, B., Ridgwell, A., Schmidt, D.N., Thomas, E., Gibbs, S.J., Sluijs, A., Zeebe, R., Kump, L., Martindale, R.C., Greene, S.E., Kiessling, W., Ries, J., Zachos, J.C., Royer, D.L., Barker, S., Marchitto, T.M., Moyer, R., Pelejero, C., Ziveri, P., Foster, G.L., Williams, B., 2012. The geological record of ocean acidification. Science 335, 1058-1063.

Hüning, A., Melzner, F., Thomsen, J., Gutowska, M.A., Kramer, L., Frickenhaus, S. Rosenstiel, P., Portner, H.O., Philipp, E.E.R., Lucassen, M., 2013. Impacts of seawater acidification on mantle gene expression patterns of the Baltic Sea blue mussel: implications for shell formation and energy metabolism. Mar. Biol. 160, 1845-1861.

Intergovernmental Panel on Climate Change (IPCC), 2007. Climate change 2007: the physical science basis. In: Solomon, S., et al. (Eds.), Contribution of Working Group I to the Fourth Assessment Report of the Intergovernmental Panel on Climate Change. Cambridge Univ. Press, Cambridge, U.K.

Istin, M., Girard, J.P., 1970. Dynamic state of calcium reserves in freshwater clam mantle. Calcif. Tissue Res. 5, 196-205.

Itoh, A., Fujinoki, M., 2008. Tissue specificity of tropomyosin isoform in the mussel, Mytilus galloprovincialis. J. Electrophoresis 52, 47-52.

Ji, C., Wu, H., Wei, L., Zhao, J., Lu, H., Yu, J., 2013a. Proteomic and metabolomic analysis of earthworm Eisenia fetida exposed to different concentrations of $2,2^{\prime}, 4,4^{\prime}-$ tetrabromodiphenyl ether. J. Proteome 91, 405-416.

Ji, C., Wu, H., Wei, L., Zhao, J., Yu, J., 2013b. Proteomic and metabolomic analysis reveal gender-specific responses of mussel Mytilus galloprovincialis to 2,2',4,4'tetrabromodiphenyl ether (BDE 47). Aquat. Toxicol. 140, 449-457.

Ji, C., Wu, H., Wei, L., Zhao, J., Wang, Q., Lu, H., 2013c. Responses of Mytilus galloprovincialis to bacterial challenges by metabolomics and proteomics. Fish Shellfish Immunol. 35, 489-498.

Jury, C.P., Whitehead, R.F., Szmant, A.M., 2010. Effects of variations in carbonate chemistry on the calcification rates of Madracis auretenra (= Madracis mirabilis sensu Wells, 1973): bicarbonate concentrations best predict calcification rates. Glob. Chang. Biol. $16,1632-1644$.

Kakoi, S., Kin, K., Miyazaki, K., Wada, H., 2008. Early development of the Japanese Spiny Oyster (Saccostrea kegaki): characterization of some genetic markers. Zool. Sci. 25, 455-464.

Katayama, H., Nagasu, T., Oda, Y., 2001. Improvement of in-gel digestion protocol for peptide mass fingerprinting by matrix-assisted laser desorption/ionization time-of-flight mass spectrometry. Rapid Commun. Mass Spectrom. 15, 1416-1421.
Kultz, D., 2003. Evolution of the cellular stress proteome: from monophyletic origin to ubiquitous function. J. Exp. Biol. 206, 3119-3124.

Kultz, D., 2005. Molecular and evolutionary basis of the cellular stress response. Annu. Rev. Physiol. 67, 225-257.

Lannig, G., Eilers, S., Portner, H.O., Sokolova, I.M., Bock, C., 2010. Impact of ocean acidification on energy metabolism of oyster, Crassostrea gigas: changes in metabolic pathways and thermal response. Mar. Drugs 8, 2318-2339.

Lee, F.W.F., Lo, S.C.L., 2008. The use of Trizol reagent (phenol/guanidine isothiocyanate) for producing high quality two-dimensional gel electrophoretograms (2-DE) of dinoflagellates. J. Microbiol. Methods 73, 26-32.

Lewis, E., Wallace, D., 1998. Program Development for $\mathrm{CO}_{2}$ System Calculations; Carbon Dioxide Information Analysis Center, Oak Ridge National Laboratory. Oak Ridge, TN, USA.

Michaelidis, B., Haas, D., Grieshaber, M.K., 2005. Extracellular and intracellular acid-base status with regard to the energy metabolism in the oyster Crassostrea gigas during exposure to air. Physiol. Biochem. Zool. 78, 373-383.

Millero, F.J., Graham, T.B., Huang, F., Bustos-Serrano, H., Pierrot, D., 2006. Dissociation constants of carbonic acid in seawater as a function of salinity and temperature. Mar. Chem. 100, 80-94.

Minárik, P., Tomaskova, N., Kollarova, M., Antalik, M., 2002. Malate dehydrogenasesstructure and function. Gen. Physiol. Biophys. 21, 257-265.

Morse, J.W., Andersson, A.J., Mackenzie, F.T., 2006. Initial responses of carbonate-rich shelf sediments to rising atmospheric $\mathrm{pCO}_{2}$ and "ocean acidification": role of high $\mathrm{Mg}$ calcites. Geochim. Cosmochim. Acta 70, 5814-5830.

Mortz, E., Krogh, T.N., Vorum, H., Gorg, A., 2001. Improved silver staining protocols for high sensitivity protein identification using matrix-assisted laser desorption/ ionization-time of flight analysis. Proteomics 1, 1359-1363.

Moullac, G.L., Bacca, H., Huvet, A., Moal, J., Pouvreau, S., Wormhoudt, A.V., 2007. Transcriptional regulation of pyruvate kinase and phosphoenolpyruvate carboxykinase in the adductor muscle of the oyster Crassostrea gigas during prolonged hypoxia. J. Exp. Zool. A Ecol. Genet. Physiol. 307A, 371-382.

Navarro, J.M., Torres, R., Acuna, K., Duarte, C., Manriquez, P.H., Lardies, M., Lagos, N.A. Vargas, C., Aguilera, V., 2013. Impact of medium-term exposure to elevated $p \mathrm{CO}_{2}$ levels on the physiological energetics of the mussel Mytilus chilensis. Chemosphere 90, 1242-1248.

Nesto, N., Bertoldo, M. Nasci, C., Da Ros, L, 2004. Spatial and temporal variation of biomarkers in mussels (Mytilus galloprovincialis) from the Lagoon of Venice, Italy. Mar. Environ. Res. 58, 287-291.

O'farrell, P.H., 1975. High-resolution 2-dimensional electrophoresis of proteins. J. Biol Chem. 250, 4007-4021.

Parker, L.M., Ross, P.M., O'Connor, W.A., 2009. The effect of ocean acidification and temperature on the fertilization and embryonic development of the Sydney rock oyster Saccostrea glomerata (Gould 1850). Glob. Chang. Biol. 15, 2123-2136.

Parker, L.M., Ross, P.M., O'Connor, W.A., 2010. Comparing the effect of elevated $p \mathrm{CO}_{2}$ and temperature on the fertilization and early development of two species of oysters. Mar. Biol. 157, 2435-2452.

Parker, L.M., Ross, P.M., O'Connor, W.A., 2011. Populations of the Sydney rock oyster Saccostrea glomerata, vary in response to ocean acidification. Mar. Biol. 158, 689-697.

Parker, L.M., Ross, P.M., O'Connor, W.A., Borysko, L., Raftos, D.A., Portner, H.O., 2012. Adult exposure influences offspring response to ocean acidification in oysters. Glob. Chang. Biol. 18, 82-92.

Pedersen, P.L., Carafoli, E., 1987. Ion motive ATPases. I. Ubiquity, properties, and significance to cell function. Trends Biochem. Sci. 12, 146-150.

Sabine, C.L., Feely, R.A., Gruber, N., Key, R.M., Lee, K., Bullister, J.L., et al., 2004. The oceanic sink for $\mathrm{CO}_{2}$. Science 305, 367-371.

Shevchenko, A., Wilm, M., Vorm, O., Mann, M., 1996. Mass spectrometric sequencing of proteins from silver stained polyacrylamide gels. Anal. Chem. 68, 850-858.

Sydow, K., Daiber, A., Oelze, M., Chen, Z.Q., August, M., Wendt, M., Ullrich, V., Mulsch, A. Schulz, E., Keaney, J.F., Stamler, J.S., Munzel, T., 2004. Central role of mitochondrial aldehyde dehydrogenase and reactive oxygen species in nitroglycerin tolerance and cross-tolerance. J. Clin. Investig. 113, 482-489.

Szymanski, P.T., Tao, T., 1993. Interaction between calponin and smooth-muscle myosin. FEBS Lett. 331, 256-259.

Thompson, E.L., Taylor, D.A., Nair, S.V., Birch, G., Haynes, P.A., Raftos, D.A., 2011. A proteomic analysis of the effects of metal contamination on Sydney Rock Oyster (Saccostrea glomerata) haemolymph. Aquat. Toxicol. 103 (3-4), 241-249.

Thompson, E.L., Taylor, D.A., Nair, S.V., Birch, G., Haynes, P.A., Raftos, D.A., 2012. Proteomic discovery of biomarkers of metal contamination in Sydney Rock oysters (Saccostrea glomerata). Aquat. Toxicol. 109, 202-212.

Timmins-Schiffman, E., Coffey, W.D., Hua, W., Nunn, B.L. Dickinson, G.H., Roberts, S.B. 2014. Shotgun proteomics reveals physiological response to ocean acidification in Crassostrea gigas. Peerj PrePrints 2, e388v1.

Todgham, A.E., Hofmann, G.E., 2009. Transcriptomic response of sea urchin larvae Strongylocentrotus purpuratus to $\mathrm{CO}_{2}$-driven seawater acidification. J. Exp. Biol. 212 2579-2594

Tomanek, L., 2014. Proteomics to study adaptations in marine organisms to environmental stress. J. Proteome 105, 92-106.

Tomanek, L., Zuzow, M.J., Ivanina, A.V., Beniash, E., Sokolova, I.M., 2011. Proteomic response to elevated $\mathrm{pCO}_{2}$ level in eastern oysters, Crassostrea virginica: evidence for oxidative stress. J. Exp. Biol. 214, 1836-1844.

Viant, M.R., Rosenblum, E.S., Tjeerdema, R.S., 2003. NMR-based metabolomics: a powerfu approach for characterizing the effects of environmental stressors on organism health. Environ. Sci. Technol. 37, 4982-4989.

Vogel, C., Marcotte, E.M., 2012. Insights into the regulation of protein abundance from proteomic and transcriptomic analyses. Nat. Rev. Genet. 13, 227-232. 
Wang, X., Chang, L., Sun, Z., Zhang, Y., 2010. Comparative proteomic analysis of differentially expressed proteins in the earthworm Eisenia fetida during Escherichia coli 0157: H7 stress. J. Proteome 9, 6547-6560.

Weber, K., Plessmann, U., Ulrich, W., 1989. Cytoplasmic intermediate filament proteins of invertebrates are closer to nuclear lamins than are vertebrate intermediate filament proteins-sequence characterization of 2 muscle proteins of a nematode. EMBO J. 8, 3221-3227.

Welladsen, H.M., Southgate, P.C., Heimann, K., 2010. The effects of exposure to nearfuture levels of ocean acidification on shell characteristics of Pinctada fucata (Bivalvia: Pteriidae). Molluscan Res. 30, 125-130.

Winder, S.J., Walsh, M.P., 1993. Calponin-thin filament-linked regulation of smoothmuscle contraction. Cell. Signal. 5, 677-686.

Winder, S.J., Allen, B.G., Fraser, E.D., Kang, H.M., Kargacin, G.J., Walsh, M.P., 1993. Calponin phosphorylation in-vitro and in intact muscle. Biochem. J. 296, 827-836.
Wu, H., Ji, C., Wei, L., Zhao, J., 2013a. Evaluation of protein extraction protocols for 2DE in marine ecotoxicoproteomics. Proteomics 13, 3205-3210.

Wu, H., Liu, X., Zhang, X., Ji, C., Zhao, J., Yu, J., 2013b. Proteomic and metabolomic responses of clam Ruditapes philippinarum to arsenic exposure under different salinities. Aquat. Toxicol. 136, 91-100.

Wu, H., Ji, C., Wei, L., Zhao, J., Lu, H., 2013c. Proteomic and metabolomic responses in hepatopancreas of Mytilus galloprovincialis challenged by Micrococcus luteus and Vibrio anguillarum. J. Proteome 94, 54-67.

Xu, L., 2004. Methods of Chemometrics. Science Press, Beijing 221-227.

Zhang, L., Liu, X., You, L., Zhou, D., Wang, Q., Li, F., Cong, M., Li, L., Zhao, J., Liu, D., Yu, J., Wu, H., 2011. Benzo(a)pyrene-induced metabolic responses in Manila clam Ruditapes philippinarum by proton nuclear magnetic resonance $\left({ }^{1} \mathrm{H}\right.$ NMR) based metabolomics. Environ. Toxicol. Pharmacol. 32, 218-225. 